XVII Warsztaty Antropologiczne im. Profesora Janusza Charzewskiego Łódź 2016

http://dx.doi.org/10.18778/8088-439-7.06

\title{
MACIEJ HeNNEBERG
}

Wood Jones Chair of Anthropological and Comparative Anatomy, The University of Adelaide Institute of Evolutionary Medicine, University of Zurich

\section{BIOLOGICZNE KONSEKWENCJE ZMIAN W STRUKTURZE I DYNAMICE DEMOGRAFICZNEJ POPULACJI LUDZKICH W XXI WIEKU}

\section{POPULACJE LUDZKIE JAKO SYSTEMY TERMODYNAMICZNIE OTWARTE}

Pojedynczy ludzie i populacje ludzkie są systemami termodynamicznie otwartymi (Strzałko i in. 1981). Oznacza to, że energia i materia nieustannie przepływają przez takie systemy, a co za tym idzie, nie są one statyczne lecz zmieniają się dynamicznie poprzez nieustanną wymianę ich elementów $\mathrm{z}$ otoczeniem. Choć organizm ludzki jest w zasadzie systemem termodynamicznie otwartym, niektóre jego elementy, w tym również wyposażenie genetyczne, podlegają wzrostowi entropii na skutek gromadzenia się błędów w replikacji DNA, w przebiegu procesów metabolicznych i urazów struktur anatomicznych. W końcu organizm przestaje funkcjonować i umiera. Dlatego jedynym sposobem zapewnienia stałego istnienia populacji ludzkich jest zastępowanie ginących osobników poprzez osobniki tworzone na nowo - proces reprodukcji. Poprzez proces reprodukcji wieloosobnicza populacja ludzka staje się prawdziwym systemem termodynamicznie otwartym, to znaczy, że może istnieć w nieskończoność gdy spełniona jest podstawowa zależność ekologiczna (Henneberg i Ostoja-Zagórski 1984; Henneberg i Wolański 2009):

$$
C \times E \geq S
$$

gdzie: $C$ - zasoby środowiska, $E$ - zdolność eksploatacyjna populacji, $S$ - suma potrzeb życiowych populacji.

Zdolność eksploatacyjna populacji zależy od sprawności technologii używanych do pozyskiwania dóbr $(T)$ i siły roboczej dostępnej populacji $(W)$. Sumę potrzeb życiowych można podzielić na potrzeby żywnościowe $(N)$, 
higieniczne $(H)$, zapewnienie działania procesów technologicznych $\left(I_{t}\right)$ i organizacyjnych $(O)$, czyli:

$$
C \times T \times W \geq N+H+I_{t}+O
$$

Łatwo zauważyć, że zmienne $W, N$ i $H$ zależą od liczby osób w populacji i ich cech takich jak płeć, wiek, wykształcenie i sytuacja kulturowa. Demografia, nauka uważana za społeczną, dostarcza danych dla opisania podstawowej zależności ekologicznej. Ponieważ reprodukcja jest jedynym sposobem zapewnienia kontynuacji istnienia populacji, a polega ona na przekazywaniu potomstwu genów determinujących rozwój osobniczy, ruch naturalny (zgony, urodzenia i przyrost naturalny) dokumentowany przez demografów pozwala ocenić sposób przekazywania genów z pokolenia na pokolenie.

\section{WIELKOŚĆ POPULACJI, GECTOŚĆ ZALUDNIENIA I STRUKTURA GENETYCZNA}

Najprostszą zmienną demograficzną jest wielkość populacji. Z punktu widzenia biologii wartość tej zmiennej pozwala określić potrzeby życiowe jak również wielkość puli genów. Wielkość puli genów determinuje działanie dryfu genetycznego:

$$
F=1 / 2 N_{e}
$$

gdzie: $F$ - prawdopodobieństwo homozygotyczności, $N_{e}$ - efektywna wielkość populacji, która w przybliżeniu równa jest liczbie osób uczestniczących w produkcji potomstwa.

Z upływem czasu, a ściślej mówiąc liczby pokoleń, homozygotyczność populacji wzrasta odwrotnie proporcjonalnie do jej wielkości, o ile nie działają inne czynniki ewolucji. Prawdopodobieństwo homozygotyczności mierzy również wsobność przeciętnego osobnika danej populacji a zatem stopień spokrewnienia z innymi osobnikami. Wsobność jest zjawiskiem niekorzystnym ponieważ ogranicza zmienność genetyczną, która jest warunkiem przystosowywania się do zmieniających okoliczności.

W przeszłości wiele populacji było odizolowanych od innych populacji i miało niewielkie rozmiary, a więc istniała sposobność do działania dryfu genetycznego, który różnicował charakterystyki pul genów. Znaczny wzrost liczebności populacji od drugiej połowy XX wieku, i większe natężenie ruchu wędrówkowego spowodowały, że obecnie dryf genetyczny nie odgrywa istotnej roli. Rycina 1 przedstawia wielkość populacji wszystkich krajów świata. Poza bardzo nielicznymi wyjątkami małych wysp, populacje poszczególnych państw są bardzo liczne. 


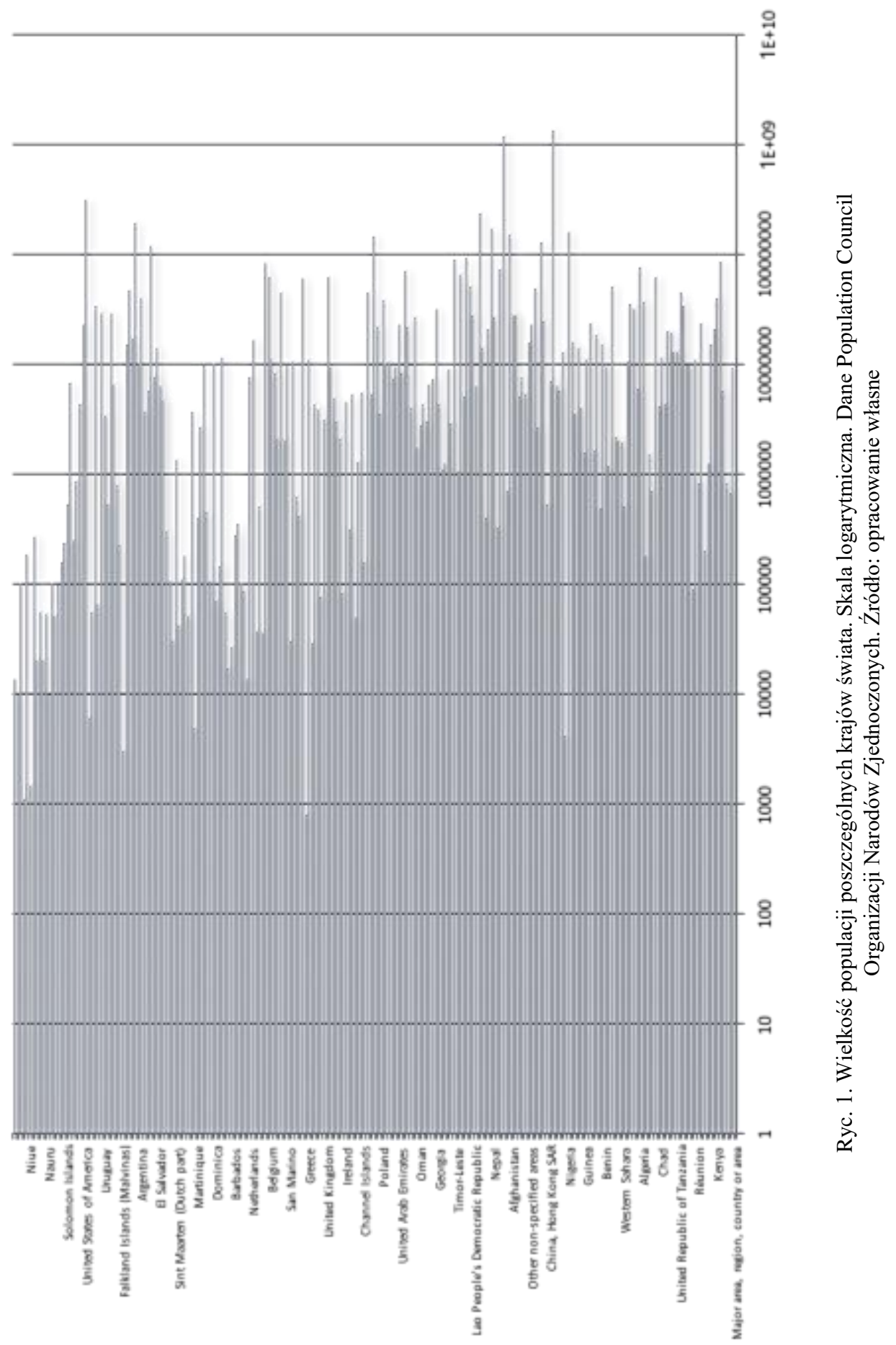


Mimo wzrostu liczebnego populacji większości krajów, rozmieszczenie przestrzenne ludności, mierzone gęstością zaludnienia, jest bardzo nierównomierne. Odzwierciedla ono podstawową prawidłowość ekologiczną - ludzie koncentrują się tam gdzie warunki środowiska zapewniają lepsze zaspokojenie ich potrzeb (ryc. 2). Najprostszym z zasobów ograniczających istnienie populacji ludzkich jest dostępność wody, która jest niezbędna do podtrzymania

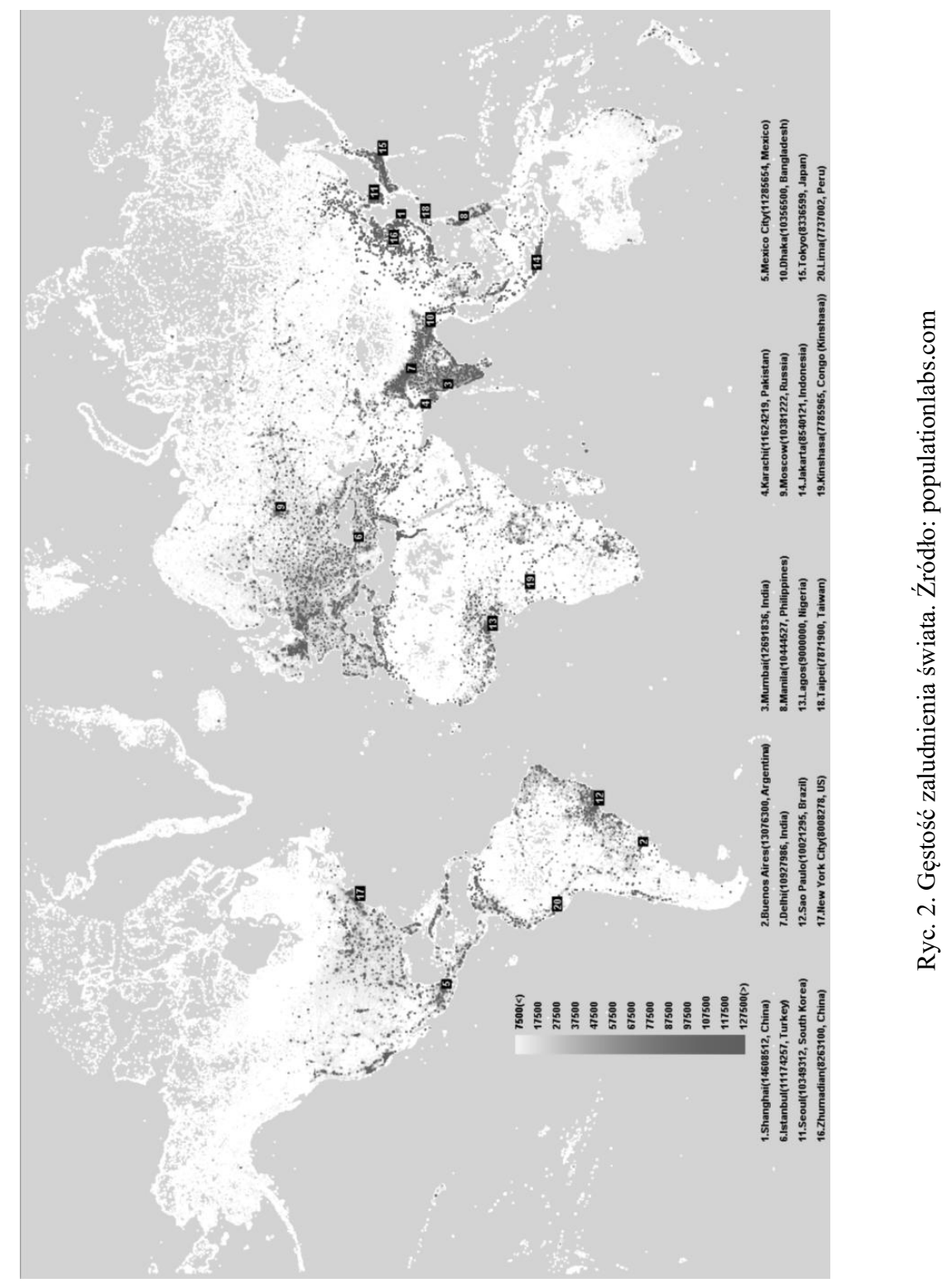


procesów metabolicznych w ciałach ludzkich, do produkcji żywności i do podstawowych zabiegów higienicznych. Morza, zbiorniki i cieki wodne zapewniają również tani transport. Na mapie gęstości zaludnienia obecnego świata zaznaczają się też zdolności eksploatacyjne. Proszę zwrócić uwagę na rycinie 2 na szereg punktów ludnościowych wzdłuż transsyberyjskiej linii kolejowej, czy na ogromną gęstość zaludnienia Jawy i przyległych części Indonezji w których irygacyjna uprawa ryżu jest najwydajniejszą na świecie techniką rolniczą.

Generalnie gęstość zaludnienia odzwierciedla podstawową zależność ekologiczną.

Rozmieszczenie ludności określa intensywność i kierunki przepływu genów między populacjami. Taki przepływ odbywa się w sposób ciągły pomiędzy sąsiadującymi osiedlami (Henneberg 1979). Jego intensywność zależy nie tylko od wielkości osiedli i ich wzajemnej odległości ale również od istnienia, lub braku, barier kulturowych, językowych i religijnych. Bariery te ulegają osłabieniu w XXI wieku w związku z globalizacją.

Przepływ genów jest również wynikiem masowych migracji, które determinowane są podstawową zależnością ekologiczną - odbywają się one z miejsc kiepsko zaspokajających podstawowe potrzeby życiowe do miejsc o bardziej zasobnym środowisku i lepszych zdolnościach eksploatacyjnych (ryc. 3). Migracje masowe nie prowadzą natychmiast do wymiany genów pomiędzy ludnością miejscową i migrantami. Aby taka wymiana zaszła $\mathrm{w}$ istotnym stopniu, trzeba przełamania barier kulturowych.

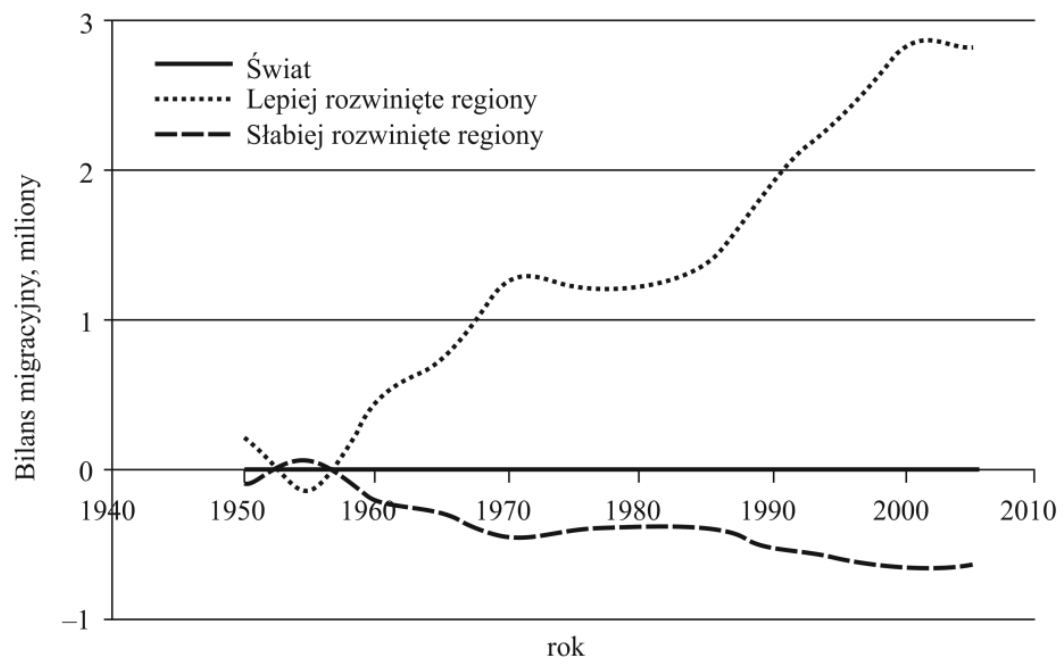

Ryc. 3. Bilans ruchu wędrówkowego na świecie. Bilans był dodatni w regionach lepiej rozwiniętych i ujemny w regionach słabiej rozwiniętych gospodarczo. Dane Population Council Organizacji Narodów Zjednoczonych. Źródło: opracowanie własne 
Podsumowując dotychczasowe rozważania można stwierdzić, że w XXI wieku niekierunkowe siły ewolucyjne w rozumieniu Sewalla Wrighta (1984) odgrywają niewielką, i stopniowo zmniejszającą się, rolę w kształtowaniu pul genetycznych populacji ludzkich dzięki wzrostowi rozmiarów populacji lokalnych i zintensyfikowaniu przepływu genów pomiędzy populacjami.

\section{RUCH NATURALNY I DZIALANIE KIERUNKOWYCH CZYNNIKÓW EWOLUCJI}

Ruch naturalny to zgony i urodzenia. Każdy umierający lub rodzący się osobnik niesie pakiet genów - indywidualny genom. Zatem ruch naturalny determinuje liczbę genomów a również ich skład gdy nosiciele szczególnych genów umierają lub rodzą się częściej niż nosiciele innych genów.

Najprostszymi miarami ruchu naturalnego są surowe współczynniki urodzeń i zgonów (ryc. 4) czyli liczby urodzeń lub zgonów wyrażone jako frakcja całkowitej wielkości populacji. Ich bilans to współczynnik przyrostu naturalnego. Łatwo zauważyć że zarówno natężenie urodzeń jak i zgonów w całym świecie malało w ciągu ostatniego półwiecza i to w taki sposób, że ich bilans - przyrost naturalny - się zmniejszał. Znaczy to, że spadek rodności był większy niż spadek umieralności. Przyrost naturalny, mimo jego zmniejszenia,

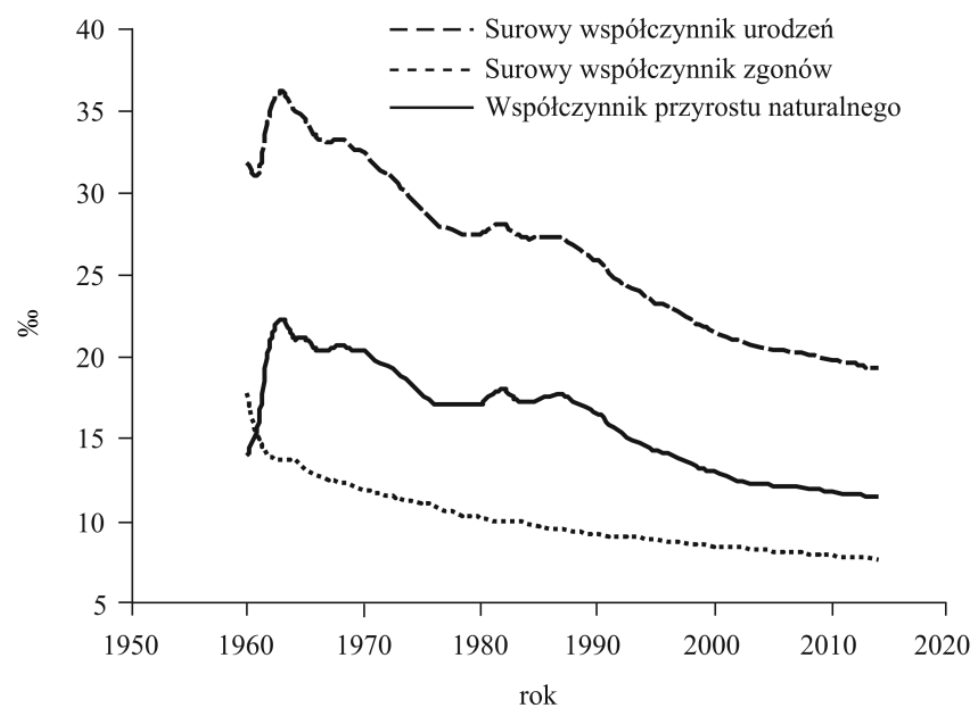

Ryc. 4. Surowe współczynniki urodzeń i zgonów na świecie i współczynnik przyrostu naturalnego. Dane Population Council Organizacji Narodów Zjednoczonych.

Źródło: opracowanie własne 
był pozytywny, co doprowadziło do wzrostu populacji światowej, ale przy zmniejszającej się rodności wzrost ten zostanie ograniczony.

Spadek wymieralności jest niewątpliwie zjawiskiem pozytywnym, oznacza że praktycznie każdy człowiek może dożyć zaawansowanego wieku. Zmniejszanie się wymieralności jest wynikiem wzrastającej zasobności i wiedzy populacji ludzkich. Natomiast spadek rodności czy płodności nie jest zjawiskiem jednoznacznie pozytywnym. W obliczu przeludnienia spadek dzietności jest pozytywny, ale powoduje on zmiany struktury wieku populacji - jej ,starzenie się". Coraz mniejsza jest proporcja dzieci i osób w wieku produkcyjnym, natomiast rośnie częstość osób w wieku po reprodukcyjnym, Osoby te częściej chorują na choroby degeneracyjne, a ich stan fizyczny z wiekiem się pogarsza. Wymaga to od społeczeństw poświęcenia więcej czasu i zasobów na opiekę nad niepełnosprawnymi a od rządów większych nakładów na służbę zdrowia. Ponieważ decyzje o posiadaniu dzieci przy powszechnie dostępnej kontroli urodzeń są oparte o sytuację ekonomiczną rodzin, w zamożniejszych społeczeństwach dzietność spada proporcjonalnie do wzrostu potrzeb materialnych małżonków prowadząc do niedostatecznej zastępowalności pokoleń (ryc. 5). Taki spadek liczby potomstwa, które zastąpi rodziców w następnym pokoleniu znacznie ogranicza sposobność przekazywania genów, która uniezależnia się od biologicznych cech rodziców będąc zależna od ich decyzji ekonomicznych.

Kierunkowe czynniki ewolucji to mutacje i dobór naturalny. Mutacje są nieuniknioną konsekwencją kiepskiej jakości wiązań chemicznych w cząsteczkach DNA. Występują one spontanicznie, lub pod wpływem czynników mutagennych takich jak promieniowanie czy niektóre związki chemiczne. Wraz ze wzrostem zdolności eksploatacyjnych populacji ludzkich pojawiają się, jako produkty uboczne rozmaitych technologii, czynniki mutagenne. Ich oddziaływanie jest ograniczane poprzez odpowiednie zabezpieczenia które wprowadza się po rozpoznaniu mutagenności specyficznych procedur lub produktów.

Obecnie ocenia się że genom noworodka zawiera przeciętnie 74 mutacje punktowe odróżniające go od genomów rodziców (Conrad i in. 2011). Wiele $\mathrm{z}$ tych mutacji może być neutralnych ale zgodnie $\mathrm{z}$ teorią Prawdopodobnego Efektu Mutacji (Brace 1964) przeciętny efekt mutacji jest szkodliwy dla organizmu ponieważ mutacje zachodzące losowo nie poprawiają sensowności informacji genetycznej a raczej ją naruszają. Zakładając, że tylko 0,1 wszystkich mutacji może mieć szkodliwe skutki dla funkcjonowania organizmu człowieka należy oszacować, że w puli genów ludzkości pojawi się 518.000.000 szkodliwych mutacji w ciągu następnych 30 lat, o ile wielkość populacji nie ulegnie zmianie. Oznacza to, że około 7,5\% ludzi będzie dotkniętych wadami genetycznymi. Jest to poważna liczba, nawet jeśli niektóre wady mają niewielkie znaczenie dla codziennego funkcjonowania organizmu, jak na przykład daltonizm. Wobec takiego oszacowania zachodzi pytanie dlaczego dotąd nie 


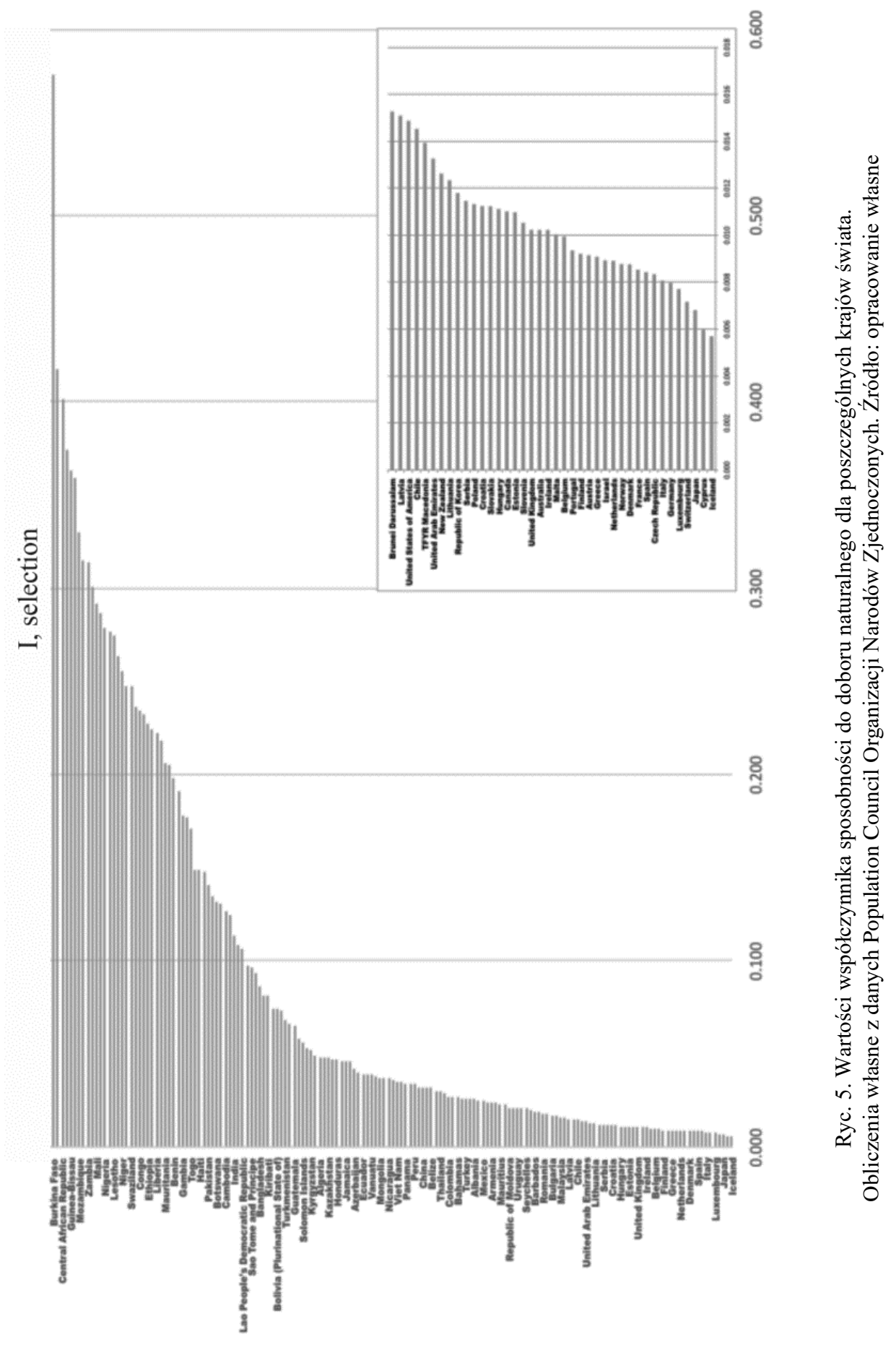


nastąpiła znaczna akumulacja mutacji? Nie nastąpiła ponieważ działał dobór naturalny.

Podstawową, codzienną rolą doboru naturalnego jest eliminacja genów szkodliwych dla procesu ludzkiej reprodukcji a zatem genów przyczyniających się do przedwczesnych zgonów i niskiej płodności. Dobór działa poprzez zróżnicowanie sukcesu reprodukcyjnego nosicieli różnych alleli. Jakkolwiek czasem trudno jest zmierzyć działanie doboru na poszczególną cechę determinowaną dziedzicznie, całkowite natężenie działania doboru naturalnego można pomierzyć poprzez ocenę wariancji tej części reprodukcji, która jest odziedziczalna (Crow 1958):

$$
I=\left(V / x^{2}\right) h^{2}
$$

gdzie: $V$ - wariancja liczby potomstwa dożywającego wieku rodziców, $x$ - przeciętna liczba potomstwa pary rodziców, $h$ - współczynnik odziedziczalności liczby potomstwa.

Odziedziczalność wymieralności wynosi około 0,25 (Cavalli-Sforza i Bodmer 1971), podczas gdy odziedziczalność płodności jest bardzo nikła, znacznie mniej niż 0,10 (Henneberg, 1980). Stąd w praktyce można oceniać całkowitą sposobność do działania doboru naturalnego (jego górną granicę) biorąc pod uwagę wymieralność. James Crow (1958) zaproponował by wariancję wymieralności $\left(I_{m}\right)$ mierzyć jako stosunek proporcji osób umierających przed osiągnięciem wieku reprodukcyjnego $\left(P_{d}\right)$ do osób przeżywających do okresu zdolności reprodukcyjnej $\left(P_{s}\right)$ :

$$
I_{m}=P_{d} / P_{s}
$$

Takie podejście jest słuszne gdy osobniki danego gatunku produkują potomstwo tylko raz $\mathrm{w}$ ciągu ich życia. Ludzie mają długi okres zdolności rozrodczej - około 30 lat - w związku z czym dobór naturalny działa również poprzez różnicową wymieralność dorosłych w różnym wieku (Henneberg, 1976a). Stąd skonstruowano wskaźnik potencjalnej reprodukcji brutto $-R_{p o t}$ (Henneberg 1975, 1976b), który waży zgony osób dorosłych ich dalszą wartością reprodukcyjną. Ta wartość $\left(s_{x}\right)$ jest ilorazem liczby dzieci urodzonych do wieku x lat i całkowitej liczby urodzeń w ciągu całego życia (TFR - total fertility rate). Dla przykładu osoba umierająca $\mathrm{w}$ wieku 30 lat może mieć $\mathrm{s}_{30}$ $=0,5$ jeśli urodziła już połowę liczby potomstwa jaką $\mathrm{w}$ jej populacji rodzą kobiety w ciągu całego życia. Dla osób po menopauzie $\mathrm{s}_{50}=0$ bo ich zgon nie powoduje już straty potencjału rozrodczego, natomiast dla osób bardzo młodych $\mathrm{s}_{15-19}=0,95$ bo ich zgon powoduje praktycznie całkowitą stratę potencjału reprodukcyjnego. Wartości $s_{x}$ zależą od rozkładu cząstkowych współczynników reprodukcji wedle wieku. W populacjach nowoczesnych, ograniczających liczbę 
urodzeń wartość $\mathbf{s}_{30}$ może wynosić 0,9 jeśli kobiety opóźniają pierwsze urodzenia do czasu osiągnięcia stabilizacji zawodowej i materialnej. Kombinacja wymieralności przed osiągnięciem wieku reprodukcyjnego z $R_{p o t}$ pozwala ocenić całkowitą stratę reprodukcyjna $\mathrm{z}$ powodu przedwczesnej wymieralności (Henneberg 1976b). Uzupełnienie tej liczby do jedności daje tzw. wskaźnik stanu biologicznego $\left(I_{b s}\right)$ mierzący prawdopodobieństwo z jakim przeciętny osobnik danej populacji może uczestniczyć w produkcji osobników następnego pokolenia:

$$
I_{b s}=1-\sum_{i=0}^{w} d_{x} s_{x}
$$

gdzie: $d_{x}$ - frakcja zmarłych w wieku x wśród wszystkich zmarłych, $s_{x}-$ dalsza wartość reprodukcyjna osób w wieku $x, w$ - wiek najstarszego osobnika w danej populacji.

Wartość $I_{b s}$ jest dokładną miarą proporcji osób przeżywających by się w pełni zreprodukować, a zatem dokładniejszą niż wskaźnik Crowa miarą całkowitej sposobności do działania doboru naturalnego jest:

$$
I=\left(1-I_{b s}\right) / I_{b s}
$$

Biorąc pod uwagę znikomą odziedziczalność płodności i jej obecnie silną kontrolę zależną od czynników niegenetycznych (społeczno-ekonomicznych), miara ta oparta na wymieralności odzwierciedla w praktyce całkowitą sposobność do działania doboru naturalnego w populacjach współczesnych. Rzeczywista intensywność działania doboru naturalnego może być mniejsza od tej wartości, ale nie może jej przekroczyć.

Jest oczywiste, że omówione wskaźniki mogą tylko mierzyć działanie doboru naturalnego w życiu pozamacicznym. Nie uwzględniają one doboru gametycznego i wewnątrzmacicznego (Rühli i Henneberg 2016). Te rodzaje doboru odgrywają poważną rolę w kształtowaniu puli genów, trudno jednak precyzyjnie mierzyć ich rozmiary. Mamy przykłady zmniejszania się ich intensywności $\mathrm{w}$ ostatnich dziesięcioleciach $\mathrm{w}$ postaci wzrostu częstości wariantów anatomicznych takich jak spina bifida occulta (Solomon i in. 2009; Lee $\mathrm{i}$ in. 2011) czy tętnica pośrodkowa przedramienia (Henneberg i George 1995) ale całości nie potrafimy jeszcze ocenić.

Wraz ze spadkiem wymieralności w ostatnim półwieczu zmniejszyła się sposobność do działania doboru naturalnego, szczególnie wyraźnie w krajach rozwiniętych gospodarczo (ryc. 6). Istnieje prosta i dramatycznie wykładnicza, zależność pomiędzy dochodem na głowę mieszkańca kraju i sposobnością do działania doboru naturalnego w tym kraju (ryc. 7). 


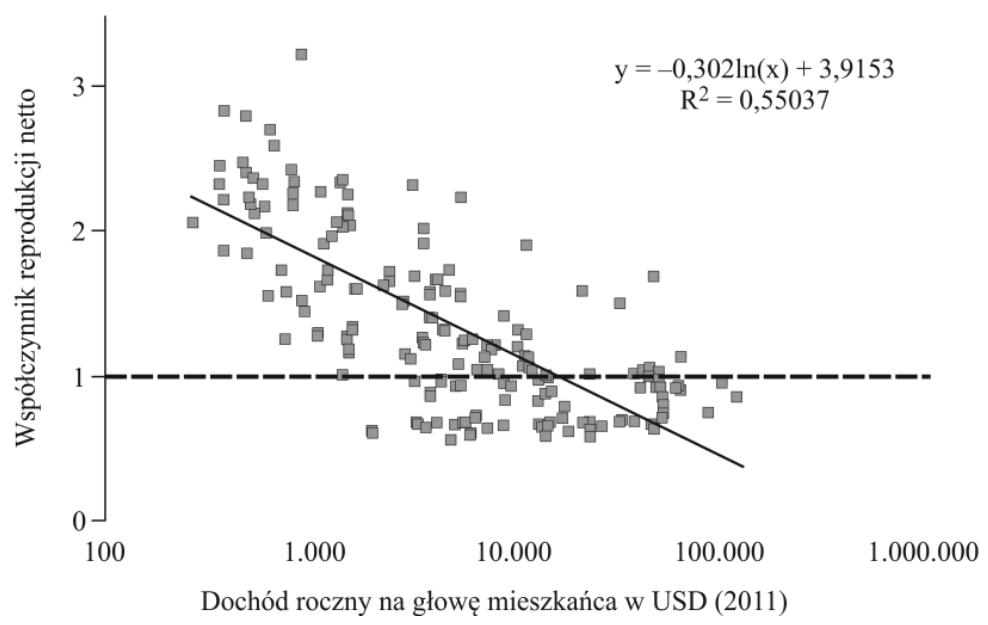

Ryc. 6. Zależność wartości współczynnika reprodukcji netto (liczby dzieci zastępujących jednego rodzica w następnym pokoleniu) od dochodu na głowę mieszkańca dla 160 krajów świata.

Obliczenia własne na podstawie danych Population Council Organizacji Narodów Zjednoczonych i Banku Światowego. Przerywana linia oznacza współczynnik reprodukcji prostej czyli zastępowalności liczbowej pokoleń. Proszę zwrócić uwagę, że w wielu krajach wartości współczynnika są poniżej 1,0. Źródło: opracowanie własne

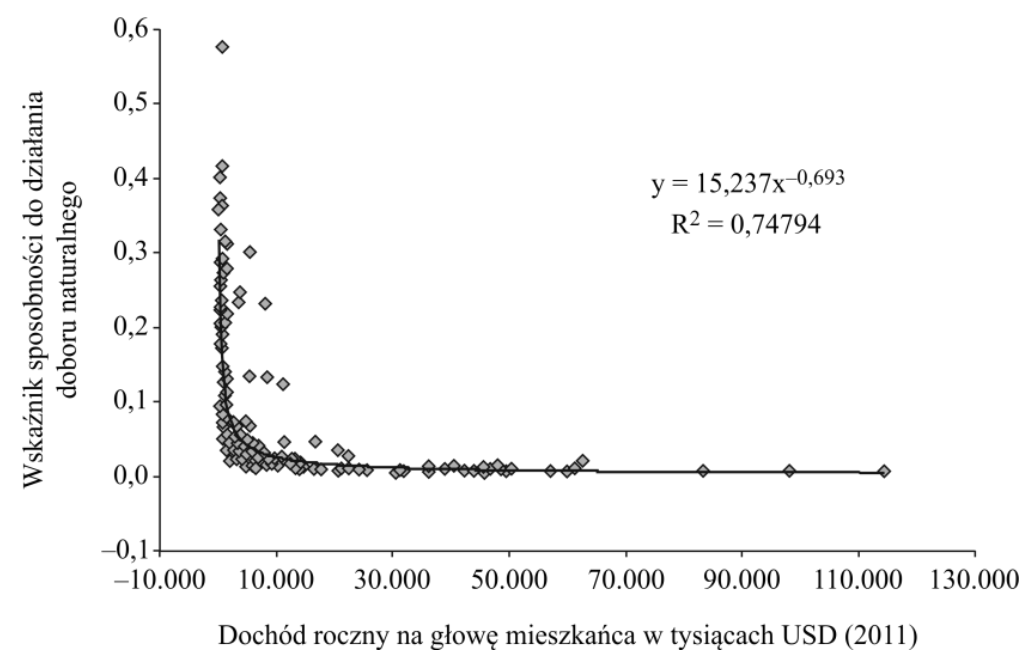

Ryc. 7. Zależność wielkości współczynnika sposobności do działania doboru naturalnego od dochodu na głowę mieszkańca dla 160 krajów świata. Obliczenia własne na podstawie danych Population Council Organizacji Narodów Zjednoczonych i Banku Światowego. Źródło: opracowanie własne 
Szybki spadek sposobności do działania doboru naturalnego w zamożniejszych krajach spowodował wzrost częstości osób z cukrzycą pierwszego typu (You i Henneberg 2016a) i wyraźny wzrost zapadalności na choroby nowotworowe wśród osób poniżej 50 roku życia (You i Henneberg 2016b) (ryc. 8).

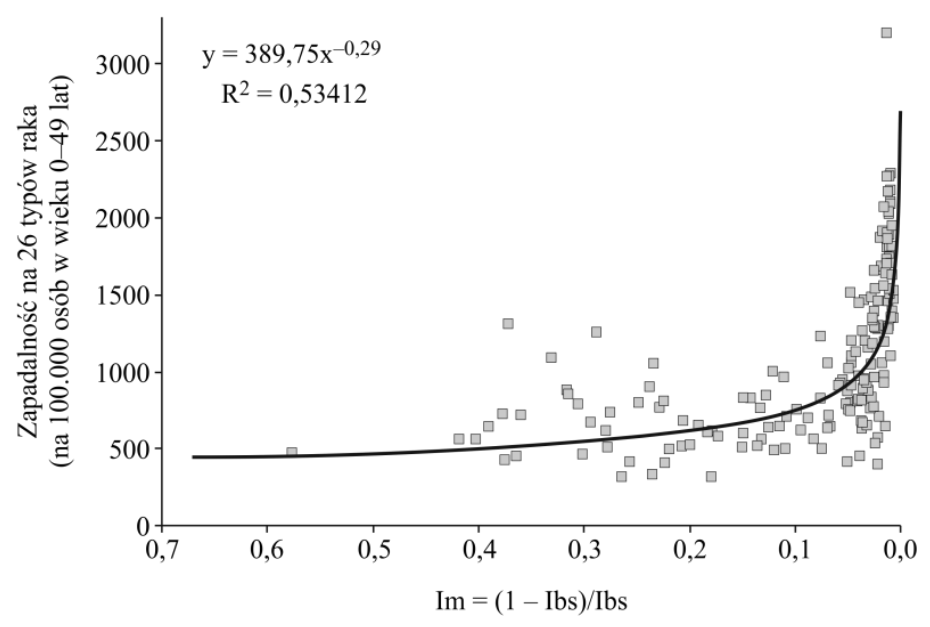

Ryc. 8. Zależność zapadalności na 26 rodzajów chorób nowotworowych od sposobności do działania doboru naturalnego. Obliczenia własne na podstawie danych Globocan (Ferlay 2012)

i Population Council Organizacji Narodów Zjednoczonych.

Źródło: You i Henneberg (2016b)

Ponieważ można oczekiwać, że zdolności eksploatacyjne populacji ludzkich będą wzrastały zapewniając coraz lepsze zaspokojenie podstawowych potrzeb życiowych, starzenie się populacji będzie wzrastać, współczynniki reprodukcji obniżą się a sposobność do działania doboru naturalnego zmaleje powodując nagromadzenie się niekorzystnych mutacji. W związku z tym nakłady na opiekę medyczną będą rosnąć. Rodzi się pytanie czy zdolności eksploatacyjne populacji ludzkich będą w stanie zaspokoić rosnące potrzeby utrzymania się ludzi przy życiu.

\section{BIBLIOGRAFIA}

Brace C.L. 1964. The probable mutation effect. The American Naturalist, 98(903): 453-455. Cavalli-Sforza L.L., Bodmer W. 1971. Human population genetics. Freeman, San Francisco. Conrad D.F., Keebler J.E., DePristo M.A., Lindsay S.J., Zhang Y., Cassals F., Idaghdour Y., Hartl C.L., Torroja C., Garimella K.V., Zilversmit M. 2011. Variation in genome-wide mutation rates within and between human families. Nature genetics, 43(7): 712-714. 
Crow J.F. 1958. Some possibilities for measuring selection intensities in man. Human Biology, 30(1): 1-13.

Ferlay J. et al. GLOBOCAN 2012 v1.0, Cancer Incidence and Mortality Worldwide. IARC Cancer Base No. 11 [Internet]. Available from: http://globocan.iarc.fr, 28.05.2016.

Henneberg M. 1975. Notes on the reproduction possibilities of earlier human populations. Przegląd Antropologiczny, 41: 75-89.

Henneberg M. 1976a. The influence of natural selection on brachycephalization in Poland. Studies in Physical Anthropology, 2: 3-19.

Henneberg M. 1976b. Reproductive possibilities and estimations of the biological dynamics of earlier human populations. Journal of Human Evolution, 5: 41-48.

Henneberg M. 1979. Breeding isolation between populations: theoretical model of mating distances distribution. Studies in Physical Anthropology, 5: 81-94.

Henneberg M. 1980. Intensywność działania doboru naturalnego przez różnicowa plodność w populacjach ludzkich - ocena ilościowa. Przegląd Antropologiczny, 46: 21-60.

Henneberg M., Ostoja-Zagorski J. 1984. Use of a general ecological model for the reconstruction of prehistoric economy: The Halstatt Period culture of northwestern Poland. Journal of Anthropological Archaeology, 3:41-78.

Henneberg M., George B.J. 1995. Possible secular trend in the incidence of an anatomical variant: median artery of the forearm. American Journal of Physical Anthropology, 96(4): 329-334.

Henneberg M., Wolanski N. 2009. Human ecology, economy and the global system. [in:] Nas P.J.M., Jijiao Z. (eds.) Anthropology Now. Beijing: Intellectual Property Rights Publishing House, pp. 356-369.

Lee Y.C., Solomon L.B., Rühli F.J., Schiess R., Öhrström L., Sullivan T., Alkadhi H., Henneberg M. 2011. Confirmation of microevolutionary increase in spina bifida occulta among Swiss birth cohorts. European Spine Journal, 20(5): 776-780.

Rühli, F., Henneberg, M., 2016. Biological future of humankind: Ongoing evolution and the impact of recognition of human biological variation. [in:] Tibayrenc M., Ayala F.J. (eds.) On Human Nature. Amsterdam: Academic Press, pp. 263-275.

Solomon L.B., Rühli F.J., Lee Y.C., Henneberg M. 2009. Secular trend in the opening of the sacral canal: an Australian study. Spine, 34(3):244-248.

Strzałko J., Henneberg M., Piontek J. 1981. Populacje ludzkie jako systemy biologiczne. Warszawa: PWN.

Wright S. 1984. Evolution and the genetics of populations. Chicago: University of Chicago Press.

You W.P., Henneberg M. 2016a. Type 1 diabetes prevalence increasing globally and regionally: the role of natural selection and life expectancy at birth. BMJ Open Diabetes Research \& Care, 4(1): e000161.

You W.P., Henneberg M. 2016b. Cancer incidence increasing globally: The role of relaxed natural selection. Evolutionary Applications, submitted. 